POLSKA AKADEMIA UMIEJĘTNOŚCI

Tom XIV

PRACE KOMISJI HISTORII NAUKI PAU

2015

Michał KOKOWSKI

Instytut Historii Nauki im. Ludwika i Aleksandra Birkenmajerów

Polskiej Akademii Nauk

michal.kokowski@gmail.com

\title{
UWAGI DO KOMENTARZA \\ DR. PAWLA E. TOMASZEWSKIEGO \\ NA TEMAT BADAŃ ŻYCIORYSU \\ JANA CZOCHRALSKIEGO (REPLIKA)
}

\begin{abstract}
Streszczenie
Autor udziela odpowiedzi na tekst dr. Pawła E. Tomaszewskiego pt. „Uwagi do komentarza prof. Michała Kokowskiego o badaniach życiorysu Jana Czochralskiego” (Tomaszewski 2015), uwypukla kluczowe kwestie sporne, w tym potrzebę systematycznego powoływania się na źródła historyczne i ich krytykę.
\end{abstract}

Słowa kluczowe: Jan Czochralski, analiza dokumentów, biografistyka

\section{Wstęp}

Celem niniejszego artykułu jest dokonanie krytycznej analizy tekstu dr. Pawła E. Tomaszewskiego (2015). Przedstawiane uwagi dotyczą zarówno zagadnień szczegółowych, jak i kwestii ogólnych, omawianych we wcześniejszym artykule (Kokowski 2014), które następnie zostały podjęte przez dr. Tomaszewskiego (2015).

\section{Kwestie szczegółowe}

\section{Ad. 1) Początki kariery}

We wcześniejszym artykule (Kokowski 2014) odniosłem się krytycznie do tezy dr. Pawła Tomaszewskiego o „wychowania w duchu polskości” w rodzinie Czochralskich, mieszkającej w Kcyni, w zaborze pruskim. Stwierdziłem w tym kontekście:

[...] Przywołane przez Autora [Tomaszewski 2014, s. 60] „wychowywanie w duchu polskim", które miałoby polegać na unikaniu wszelkich kontaktów z Niemcami byłoby wyrazem postawy nacjonalistycznej (niemożliwej w ogóle do realizacji w ówczesnej Kcyni ze względów praktycznych). Warto podkreślić, że rodzina Czochralskich z Kcyni nie utożsamiała jednak „wychowywania w duchu polskości” z taką postawą, o czym świad-




czy sam wyjazd Jana Czochralskiego z Kcyni do stolicy Niemiec i cała jego kariera zawodowa w tym kraju [...] (Kokowski 2014, s. 134).

Dr Tomaszewski (2015) nie zgadza się jednak z taką krytyką:

Interpretacja zdania o wychowaniu w duchu polskości jako unikaniu wszelkich kontaktów z Niemcami i przejawu „postawy nacjonalistycznej” jest tylko i aż nadinterpretacją. Nie można też zapominać, że były to czasy zaborów i wyjazd do „stolicy Niemiec” nie miał nic wspólnego ze współczesną nam emigracją Polaków do RFN.

Nie podzielam opinii dr. Tomaszewskiego, że mój krytyczny komentarz jest nadinterpretacją. Dodam, że suponowany brak kontaktów Polaków z Niemcami w zaborze pruskim jako wyraz „wychowania w duchu polskim” (Tomaszewski 2014, s. 60) jest życiowo i historycznie naiwny.

\section{Ad. 2) Kwestia wykształcenia}

Możliwe, że dr. Tomaszewski (2015) ma rację, twierdząc, że Czochralski wbrew swoim własnym słowom nie był wolnym słuchaczem żadnej niemieckiej uczelni. Mogło być jednak inaczej, gdyż - choć nie zachowały się żadne dokumenty źródłowe na ten temat Czochralski kilkakrotnie potwierdzał ten fakt.

\section{Ad.3) Kwestia współpracy $z$ wywiadem}

Fragment wspomnianej już pracy (Kokowski 2014) brzmi:

Dokumentów tego rodzaju [świadczących o współpracy Czochralskiego z wywiadem polskim przed 1928 rokiem] nie ujawniły też kwerendy w centralnych archiwach państwowych i Muzeum Politechniki Warszawskiej przeprowadzone na prośbę Komisji Historycznej Politechniki Warszawskiej, dlatego nie znajdujemy ich w publikacji Mirosława Nadera (2012) ani na stałej wystawie Muzeum Politechniki Warszawskiej „Jan Czochralski - działalność na niwie nauki” (której wernisaż odbył się 16 grudnia 2013 r.).

Dr Tomaszewski (2015) uznaje te kwerendy za powierzchowne, brak jednak w jego publikacjach informacji o wynikach poszukiwań takich materiałów - czy to przeprowadzonych przez niego samego, czy przez innych badaczy.

Nie zgadzam się też $\mathrm{z}$ opinią, abym miał „nieuzasadnioną wiarę w wiedzę tzw. polskich wikipedystów":

Przypis 11 (na stronie 136) [Kokowski 2014] wskazuje na nieuzasadnioną wiarę Autora w wiedzę tzw. polskich wikipedystów. Wystarczy analiza historii wpisów i znajomość sposobu weryfikowania w Wikipedii zgłaszanych poprawek (konieczne są dwa artykuły w... gazetach, monografia to za mało!), by odrzucić wszelką nadzieję, że hasło „Czochralski” jest rzetelne! A poza tym nie mogę odpowiadać za stwierdzenia Bratkowskiego, a tym bardziej za ich rozpowszechnianie.

We wspomnianym przypisie krytykowałem właśnie ograniczoną wiedzę wikipedystów, co bezpośrednio wiąże się z recepcją publikacji dr. Tomaszewskiego o Czochralskim, w tym jego książki (Tomaszewski 2012, ss. 126-128), w której z uznaniem cytował słowa Stefana Bratkowskiego: 
Skutkiem tej wypowiedzi [Bratkowskiego, cytowanej i omawianej np. w: Tomaszewski 2012, ss. 126-128] szereg autorów, np. Cieśliński 2011 [kilkukrotnie powołuje się na dr. Tomaszewskiego] i jego śladem polscy wikipedyści, uznali, że Stefan Bratkowski przeprowadził rzetelne badania, które doprowadziły do takiego wniosku: „Nie jest jasny powód przyjazdu do Polski, według badań Stefana Bratkowskiego Czochralski współpracował z polskim wywiadem wojskowym, a z Niemiec wyjechał z powodu grożącej mu dekonspiracji" (Wikipedia 2014).

\section{Ad. 4) Udział prezydenta Ignacego Mościckiego w ściągnięciu Czochralskiego do Polski}

Dr Tomaszewski podziela moją krytykę tezy o udziale prezydenta Ignacego Mościckiego w zatrudnieniu Jana Czochralskiego na stanowisku profesora Politechniki Warszawskiej:

W recenzowanym artykule [Tomaszewski 2014], niestety, powtórzyłem [chodzi o dr. Tomaszewskiego] ten funkcjonujący w obiegu publicznym skrót myślowy (Tomaszewki $\underline{2015})$.

Uzupełniając tę wypowiedź, Autor dodał, że w jego książce „jest mowa o «zaproszeniu do Polski», a nie na «stanowisko profesora»!" (Tomaszewski 2012). Mam jednak wątpliwość, czy istnieje dokument historyczny, który uzasadnia takie jednoznaczne stwierdzenie.

\section{Kwestie ogólne}

W artykule dr. Tomaszewskiego (2015) znajdujemy następującą opinię:

Wybranie kilku elementów z życiorysu prof. Jana Czochralskiego, by pokazać niedostatki warsztatu autora nie wydaje się najlepszym pomysłem na „racjonalną krytykę”. Należało raczej zrecenzować (całą) książkę, a nie szkic biografii zaprezentowany w inkryminowanym artykule.

Celem mojego komentarza (Kokowski 2014) nie było jednak „pokazanie niedostatków warsztatu autora”, lecz zwrócenie uwagi badaczy i popularyzatorów na niebezpieczeństwo tworzenia literackiej fikcji w biografii Czochralskiego poprzez niedostateczne udokumentowanie opisywanych faktów. Uwagi te nie były też oparte na założeniu, że artykuł dr. Tomaszewskiego (2014) jest już zamkniętym rozdziałem badań historycznych. Analizując tekst, dostrzegłem o wiele poważniejszą kwestię, którą najlepiej oddać własnymi słowami dr. Tomaszewskiego:

Podstawowym źródłem wiadomości o Czochralskim jest obszerna, trzystustronicowa książka pt. „Powrót. Rzecz o Janie Czochralskim” (2012) i jej nieco zmieniona i poszerzona wersja angielska (2013). Należy zaznaczyć, że nie jest to typowa książka historyczna, a tym bardziej praca naukowa. Z oczywistych względów pominięto cały aparat naukowy, by opracowanie nie tylko było przejrzyste i bardziej przystępne dla czytelnika, ale by stanowiło zarazem źródło wielu podstawowych informacji (dokumenty, spisy prac Czochralskiego i opracowań o nim) (Tomaszewski 2015). 
Otóż - jak stwierdza to sam dr Tomaszewski - nie stosował on „z oczywistych racji” aparatu krytycznego we wspomnianych powyżej dwóch głównych jego książkach. W tym właśnie upatruję zasadniczy problem dotychczasowych publikacji dr. Tomaszewskiego na temat Jana Czochralskiego.

Jednak dr Tomaszewski w swojej replice (2015) na mój komentarz (Kokowski 2014) stosuje już jawne nawiązanie do źródeł i podejmuje ich krytykę. Uważam zatem, że taka forma jego odpowiedzi dowodzi, że moja dezaprobata miała sens, gdyż unaoczniła możliwość formułowania różnych interpretacji wokół niedostatecznie udokumentowanych faktów i ich wyjaśnień oraz potrzebę powoływania się na źródła historyczne i dokonywanie krytyki takich źródeł.

I mimo iż dr Tomaszewski tylko w niewielkim stopniu zgodził się z linią oceny wątków biograficznych, którą zaproponowałem w moim komentarzu (Kokowski 2014) mam tu na myśli wspomniane powyżej kwestie szczegółowe (proszę rozsądzić czy zrobił to słusznie, czy nie) - uznał jednak za w pełni uzasadniony głoszony przez mnie kluczowy postulat, „by opublikować pełną, historycznie fachowo opracowaną biografię Jana Czochralskiego".

Dodał on jednak symptomatycznie brzmiące zdanie: „Niestety, nie widać osób, które mogłyby w «niedalekiej przyszłości» tego dokonać” (Tomaszewski 2015).

Myślę, że dr Tomaszewski ma dużo racji w tym osądzie, gdyż przyjęta przez niego nietypowa konwencja pisarska utrudnia w pewnym stopniu zarówno sprawdzanie głoszonych przez niego tez, jak i kontynuowanie jego zainteresowań badawczych.

Warto na koniec znaczyć, że nie tylko w Polsce są prowadzone badania źródłowe nad postacią Jana Czochralskiego. Tematyką tą zajmuje się na przykład dr Katrin Steffen z NordostInstitut Lueneburg z Uniwersytetu w Hamburgu, która obecnie przygotowuje habilitację na temat Jana Czochralskiego i Ludwika Hirszfelda. ${ }^{1}$

\section{Niezmienna teza}

Pomimo powyżej sformułowanych krytycznych komentarzy podtrzymuję moją tezę o wielkich, niekwestionowalnych zasługach dr. Tomaszewskiego w przybliżeniu środowisku akademickiemu i szerokiej opinii społecznej postaci Jana Czochralskiego. Bez jego aktywnych działań sylwetka uczonego nie byłaby tak powszechnie znana.

${ }^{1}$ Informacja własna uzyskana w rozmowie $\mathrm{z}$ dr Katrin Steffen podczas "Entangled Science? Relocating German-Polish Scientific Relations" (International Conference of the Cooperation Initiative of the Leibniz Association and the Polish Academy of Sciences: "Cross-border Scientific Dialogue. Potentials and Challenges for the Human and the Social Sciences", in cooperation with Ludwik and Alexander Birkenmajer Institute for the History of Science, 28-30 October 2015, The Herder Institute for Historical Research on East Central Europe - Institute of the Leibniz Association, Marburg). 


\section{BIBLIOGRAFIA}

\section{BRATKOWSKI Stefan}

1971: Księgi wróżb prawdziwych. Warszawa: Wydawnictwo Horyzonty Harcerskie.

2004: Czochralski. Niezależny Magazyn Publicystów 2004-05-18. Publikacja dostępna w Internecie: http://www.kontrateksty.pl/index.php?action=show\&type=news\&newsgroup $=16 \& i d=161(28.10 .2014)$.

2011: Czy znamy jakiś mit Czochralskiego? Studio Opinii. Publikacja dostępna w Internecie: http://alfaomega.webnode.com/news/czy\%20znamy\%20jakiś\%20mit\%20 czochralskiego (15.03.2011).

\section{CIEŚLIŃSKI Piotr}

2011: Sceny z życia patrioty, którego uznano za zdrajcę. Gazeta Wyborcza. Publikacja dostępna w Internecie: http://wyborcza.pl/1,75476,9953629.html (15.07.2011).

\section{KOKOWSKI Michał}

2014: Komentarz do artykułu dr. Pawła Tomaszewskiego. Prace Komisji Historii Nauki PAU XIII, ss. 131-140. Publikacja dostępna w Internecie: http://pau.krakow.pl/ PKHNPAU/pkhnpauXIII20148.pdf.

NADER Mirosław

2012: Sylwetka Profesora Czochralskiego - przedwojenna i okupacyjna działalność, losy powojenne. „Seminarium Jan Czochralski - światowej sławy wynalazca i inżynier” (1885-1953). Doktor honoris causa Politechniki Warszawskiej. Politechnika Warszawska, Warszawa, 27 kwietnia 2012 r. Publikacja dostępna w Internecie: http:// bcpw.bg.pw.edu.pl/Content/3576/Czochralski sylwetka.pdf (28.10.2014).

TOMASZEWSKI Paweł E.

2003: Jan Czochralski i jego metoda. Jan Czochralski and his metod. Wrocław-Kcynia: Oficyna Wydawnicza ATUT. ISBN 8389247275; płyta CD.

2012: Powrót. Rzecz o Janie Czochralskim. Wrocław: Oficyna Wydawnicza ATUT. ISBN 9788390621869, ISBN 9788374328173.

2012-2015: Biuletyn Roku Czochralskiego nr 1-140 (Wrocław). Publikacje dostępne w Internecie: Strona internetowa „prof. Jan Czochralski (23.10.1885 - 22.04.1953)” redagowana przez Sylwestra Czochralskiego; http://www.janczochralski.com/.

2013: Jan Czochralski restored. Tłumaczenie Magdalena Iwińska. Wrocław: Oficyna Wydawnicza ATUT. ISBN 9788374329453.

2014: Jan Czochralski - historia człowieka niezwykłego. Prace Komisji Historii Nauki PAU XIII, ss. 57-72. Publikacja dostępna w Internecie; http://pau.krakow.pl/PKHNPAU/pkhnpauXIII20144.pdf.

2015: Uwagi do komentarza prof. Michała Kokowskiego o badaniach życiorysu Jana Czochralskiego. Prace Komisji Historii Nauki PAU XIV, ss. 259-265. Publikacja dostępna w Internecie: http://pau.krakow.pl/PKHN-PAU/pkhn-pau-XIV-2015-11.pdf. 
WIKIPEDIA

2014: Jan Czochralski. Publikacja dostępna w Internecie: http://pl.wikipedia.org/wiki/ Jan Czochralski (28.10.2014).

\title{
REMARKS TO DR. PAUL E. TOMASZEWSKI'S COMMENTS ON THE RESEARCH OF JAN CZOCHRALSKI'S CURRICULUM VITAE (A REPLY)
}

\begin{abstract}
The author replies to the text entitled "Remarks to the comment by Prof. Michal Kokowski on the research of Jan Czochralski's biography" by Dr. Paweł E. Tomaszewski (2015), highlighting the key contentious issues, including the need to rely systematically on historical sources and the criticism thereof.

Keywords: Jan Czochralski; analysis of documents; biographical writings
\end{abstract}

